\title{
FORECASTING PASSENGER ENPLANEMENTS OF A MUNICIPAL AIRPORT: THE CASE OF MOBILE, ALABAMA
}

\author{
Semoon Chang*
}

\section{PRELIMINARY ANALYSIS}

Whether an airport facility should be expanded or not depends upon two major factors: One relates to how fast enplaned passengers of the airport increase over time, and the other, to when the present airport capacity is judged no longer adequate to provide decent services to the increasing number of passengers. This paper deals with the first problem by presenting a forecasting model of enplaned passengers at the Mobile Municipal Airport, which in fact is a summary of our work involved in reconciling high forecasts made by a local consulting firm upon request from the city officials who advocate the expansion and low forecasts made by the airline companies serving Mobile which will have to pay for the expansion if one is agreed upon.

A passenger survey made in 1973 by the David Volkert \& Associates of Mobile provides a clear picture regarding the origin and destination of passengers who enplane at the local airport. ${ }^{1}$ Although the majority $(70.4 \%)$ of passengers came from within the Mobile County, a large number of passengers came also from adjacent Baldwin (9.4\%) and Jackson $(10.9 \%)$ counties. Total population of all three counties is thus selected as one of determinants of enplaned passengers at the Mobile airport although Jackson County is located in Mississippi across the state line. The survey also indicates that about half $(50.7 \%)$ of the passengers traveled for business or official purposes while the remaining 49.3 percent, for pleasure or personal purposes. Destinations of Mobile airport passengers that were revealed during the survey included no less than 264 cities all over the country and more than 12 foreign countries, with about 50 percent of these passengers having listed the following 12 cities as their ultimate destinations; Atlanta (9.9\%), Birmingham (6.9\%), New Orleans (4.8\%), New York (4.6\%), Houston (4.3\%), Chicago (3.9\%), Los Angeles $(3.3 \%)$, District of Columbia (3.2\%), Memphis (3.0\%), Orlando (2.4\%), Miami $(2.1 \%)$, and San Francisco $(2.0 \%)$. This finding on destinations

*Associate professor of economics, University of South Alabama. This paper has been prepared for presentation at the 1979 meeting of the Southwestern Federation of Administrative Disciplines in Houston, Texas. 
strongly points toward the state of the national economy as another of determinants in forecasting local passenger enplanements.

Three additional determinants of passenger enplanements are explicitly included in the model. These are annual departures of airplanes, a dummy variable representing strikes in 1970, 1974 and 1975 by National Airlines workers, and the ratio of air fare index relative to the gasoline price index at the retail level. The air fare index is derived from the domestic average passenger-mile rates available in the Statistical Abstract of the $U$. S. The reason behind inclusion of the annual departures is that a frequent and convenient scheduling may attract additional passengers, and the inclusion of the relative air fare index is designed to incorporate a possible competition which might exist between the air transportation and other modes of transportation such as private automobiles and buses.

A limited number of studies on the demand for air transportation are available for the national level. ${ }^{2}$ These studies measure the demand in terms of revenue passenger miles and are based on a gravity model which in essence assumes that the travel between a set of cities is directly proportional to the population of the two cities and is inversely proportional to distance squared. Although studies on enplanements forecasting of the municipal airport are not available, the determinants of enplaned passengers selected for the Mobile model may be compared with those selected for a national model developed for the Federal Aviation Administration in which enplaned passengers are assumed to depend upon (1) an index of air fares in relation to the prices of private transportation, (2) income spent in the purchase of automobiles, (3) income spent in personal consumption of services, (4) number of civilians gainfully employed, (5) index of plant and equipment on order or invested in air transportation, and (6) major strikes. $^{3}$

In addition to services by such major carriers as Eastern Airlines, National Airlines and Southern Airways, Mobile has been provided with commuter services which have not necessarily been of a sustaining nature. Commuter services in recent years have been supplied by several companies which include Sun Airline (September, 1968 through May, 1969), Gulf Coast Airline (August, 1971 through November, 1971), Southeastern Commuter Airline (July, 1971 through October, 1973), and finally South Central Air Transport (August, 1976 to present). Enplaned passengers may or may not include these commuter airline passengers.

\section{THE MODEL}

Symbols used in the model are defined below:

$\mathrm{EP}=$ total enplaned passengers; EPT refers to EP including commuter airline passengers while EPC, to EP exclusive of commuter passengers.

$\mathrm{AD}=$ annual actual departures of planes; $\mathrm{ADT}$ refers to $\mathrm{AD}$ including commuter flights while ADC, to AD excluding commuter flights. 
POP $=$ total population of Mobile, Baldwin and Jackson counties.

$\mathrm{RGNP}=$ real gross national product in $\$$ millions; $1967=100$

RFARE = ratio, expressed in index, of air fare index to gasoline price index where 1967 is the base year for all price indexes.

DS = dummy variable for strikes in 1970, 1974 and 1975 all by National Airlines workers; 1 for strike years and 0 for other years.

We now postulate the following recursive model.

$$
\left[\begin{array}{ll}
\beta_{11} & 0 \\
\beta_{21} & \beta_{22}
\end{array}\right]\left[\begin{array}{l}
\mathrm{AD} \\
\mathrm{EP}
\end{array}\right]+\left[\begin{array}{llll}
\gamma_{11} & \gamma_{12} & \gamma_{13} & \gamma_{14} \\
\gamma_{21} & \gamma_{22} & \gamma_{23} & 0
\end{array}\right]\left[\begin{array}{l}
\mathrm{POP} \\
\mathrm{RGNP} \\
\mathrm{RFARE} \\
\mathrm{DS}
\end{array}\right]+\left[\begin{array}{l}
\mathrm{U}_{1} \\
\mathrm{U}_{2}
\end{array}\right]=0
$$

We normalize the model by setting $\beta_{\mathrm{ii}}$ equal to -1 and rearrange:

$$
\begin{aligned}
& \text { (2) } \mathrm{AD}=\gamma_{11} \mathrm{POP}+\gamma_{12} \mathrm{RGNP}+\gamma_{13} \mathrm{REFARE}+\gamma_{14} \mathrm{DS}+\mathrm{U}_{1} \\
& \text { (3) } \mathrm{EP}=\beta_{21} \mathrm{AD}+\gamma_{21} \mathrm{POP}+\gamma_{22} \mathrm{RGNP}+\gamma_{23} \mathrm{RFARE}+\mathrm{U}_{2}
\end{aligned}
$$

Assuming $\mathrm{E}\left(\mathrm{U}_{1}, \mathrm{U}_{2}\right)=0$, equations (2) and (3) satisfy the ordinary least squares (OLS) assumption that explanatory variables and stochastic disturbances are not correlated to each other, thus allowing one to estimate the equations with the OLS method.

From a theoretical viewpoint a simultaneous equations system also appears to be feasible when we assume that enplaned passengers represent the demand for airline services and annual departures represent the supply of airline services, and that the air fare index measures the price of these services. Our such attempt, and other alternatives based on gross regional products and local employment variables, led to results which were substantially poorer than the ones obtained from our recursive model. Equations (2) and (3) may alternatively be treated as a simultaneous equations system by estimating equation (3) with predicted values, rather than actual values, of AD obtained from equation (2). This approach led to the negative sign of $\mathrm{AD}$ in equation (3) which is contrary to our a priori expectation. An intuitive explanation of our recursive model summarized in equations (2) and (3) comes into order. Both passenger enplanements and annual departures of planes depend basically upon local and national economic conditions as indicated by POP, RGNP and RFARE. A strike by airline workers is expected to have a direct impact upon the number of plane departures, but affect passenger enplanements indirectly through the annual departures. Whether annual departures are actual ones or scheduled ones is immaterial since the difference between the two is only a few during a year. The absence of passenger enplanement variable in the annual departures equation is based on our belief, as well as on empirical 
results, that the scheduling of annual departures is determined by the size of the fundamental local demand for airline services measured in population rather than by its appearance which is reflected in current passenger enplanements. A partial evidence of this hypothesis had been observed in the 20.1 percent decline in actual plane departures, prompted by the National Airlines strike, in 1974 while passenger enplanements increased by 3.9 percent during the year with no rush in scheduled or actual departures from other carriers.

Estimates of our model based on 1962 through 1976 data are presented below. Equations (4) and (5) pertain to observations which include commuter services whereas equations (6) and (7) relate to major carriers only which exclude commuter services. Figures in the parentheses refer to standard errors of estimated coefficients while mean absolute percentage errors are shortened by MAPE.

(4) $\mathrm{ADT}=-17,523+0.0293 \mathrm{POP}+0.0099 \mathrm{RGNP}+47.0767 \mathrm{RFARE}$

$$
(0.0245) \quad(0.0040) \quad(38.1079)
$$

\section{- 957.2844 DS (642.7976)}

$$
\mathrm{R}^{2}=0.77 \quad \mathrm{SEE}=833 \quad \mathrm{D}-\mathrm{W}=1.38 \quad \mathrm{MAPE}=6.1 \%
$$

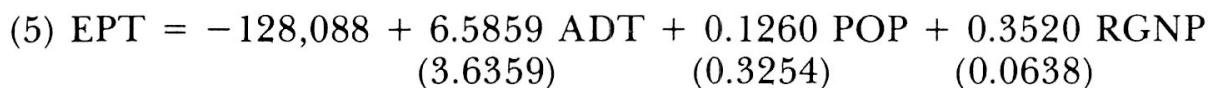

- 912.9915 RFARE

(514.3030)

$$
\mathrm{R}^{2}=0.98 \quad \mathrm{SEE}=10,586 \quad \mathrm{D}-\mathrm{W}=1.64 \quad \mathrm{MAPE}=3.23 \%
$$

(6) $\mathrm{ADC}=-20,015+0.0402 \mathrm{POP}+0.0064 \mathrm{RGNP}+46.7431 \mathrm{RFARE}$

$$
\text { (0.0249) (0.0041) (38.6943) }
$$

$$
\begin{gathered}
-518.2275 \text { DS } \\
(652.6897)
\end{gathered}
$$

$$
\mathrm{R}^{2}=0.71 \quad \mathrm{SEE}=846 \quad \mathrm{D}-\mathrm{W}=1.84 \quad \mathrm{MAPE}=6.3 \%
$$

(7) $\mathrm{EPG}=-150,146+5.0344 \mathrm{ADC}+0.1236 \mathrm{POP}+0.3820 \mathrm{RGNP}$

$$
\begin{array}{lll}
(4.0839) \quad(0.3663) \quad(0.0602)
\end{array}
$$

\section{- 781.6582 RFARE} (535.7007)

$$
\mathrm{R}^{2}=0.98 \quad \mathrm{SEE}=11,262 \quad \mathrm{D}-\mathrm{W}=1.49 \quad \mathrm{MAPE}=3.72 \%
$$

To complete our model as a recursive system, it is necessary to prove that the contemporary residuals between equations (4) and (5), and between equations (6) and (7) are uncorrelated to each other. The simple correlation coefficient between residuals of equations (4) and (5) is 0.186 while the coefficient between residuals of equations (6) and (7) is 0.065 . Put differ- 
ently, a regression estimation of residuals of equation (4) as a function of residuals of equation (5) indicates an estimated coefficient of 0.0146 with zero adjusted $R^{2}$, while the similar estimation of residuals between equations (6) and (7) indicates a coefficient of 0.0049 again with zero adjusted $\mathrm{R}^{2}$.

For our purposes, however, the most important equation in the model is equation (5) since the ultimate decision on expansion of the airport facilities will depend upon the total number of passengers using the airport. Signs of estimated coefficients in equation (5), and those in equations (4), (6) and (7), are consistent with our a priori expectations. Estimated coefficients of real GNP and annual departures in equation (5) are statistically significant at five percent and ten percent, respectively, against the two tail test. The coefficient of determination, mean absolute percentage error and the Durbin-Watson statistic of the equation all appear to be acceptable, although the last one belongs to an inconclusive region owing partly to the limited number of observations. Forecasts of enplaned passengers made by use of equation (5) are actually used during the negotiation between the City of Mobile officials and officials of the airlines serving Mobile.

\section{SENSITIVITY ANALYSIS}

One may wonder what would happen to passenger enplanements, if the Mobile area population changes by one, the real GNP changes by one million dollars, the relative air fare index changes by one, or if annual departures change by one. These questions are answered in Table 1. The impact of changes in these variables upon passenger enplanements by use of the elasticity concept is also presented in the table, and is commented on here. If total population of the tri-county area increases by one percent, enplaned passengers at the Mobile airport will increase by 0.5684 percent if commuter passengers are included, and by 0.5824 percent if commuter passengers are excluded. The impact of changes in real GNP upon enplaned passengers is more substantial in that a one percent increase in real GNP leads to 1.2288 percent increase in enplaned passengers if commuter passengers are included, and to 1.4355 percent if commuter passengers are excluded. When air fares rise faster than gasoline prices, enplaned passengers will decrease although the decrease would not be very substantial. Finally, an increase in annual (scheduled) departures by one percent will lead to 0.2577 or 0.1886 percent increase in enplaned passengers depending upon whether commuter passengers are included or excluded.

An ex post simulation, presented in Exhibit 1, of our forecasting model of enplaned passengers exclusive of commuter airline passengers looks promising. The model correctly predicted a downturn of passenger enplanements in 1970. Although the model's prediction of declining passenger enplanements in 1974 and 1975 did not materialize, the model forecasts of 1974-75 passenger enplanements were quite close to actual figures due partially to the model's overestimation in 1973. The model forecasts of passenger enplanements in 1977 were 314,100 whereas actual figures were reported as 315,000 . 
TABLE 1

IMPACT ANALYSIS

Descriptive Analysis

\begin{tabular}{|c|c|c|c|c|}
\hline Changes in & $\begin{array}{l}\text { Tri-County } \\
\text { Population } \\
\text { by one }\end{array}$ & $\begin{array}{l}\text { RGNP by } \\
\$ \text { one } \\
\text { million }\end{array}$ & $\begin{array}{l}\text { Ratio Index of } \\
\text { Air Fare to Gas } \\
\text { Price by one }\end{array}$ & $\begin{array}{l}\text { Annual } \\
\text { Departures } \\
\text { by one }\end{array}$ \\
\hline $\begin{array}{l}\text { Enplaned passen- } \\
\text { gers including } \\
\text { commuters }\end{array}$ & 0.3190 & 0.3555 & -602.9491 & 6.5859 \\
\hline $\begin{array}{l}\text { Enplaned passen- } \\
\text { gers excluding } \\
\text { commuters }\end{array}$ & 0.3260 & 0.4142 & -546.3347 & 5.0344 \\
\hline
\end{tabular}

Elasticity Analysis

\begin{tabular}{lllll}
\hline $\begin{array}{l}\text { Percentage } \\
\text { changes in }\end{array}$ & $\begin{array}{l}\text { Tri-County } \\
\text { Population } \\
\text { by one per- percent } \\
\text { cent }\end{array}$ & $\begin{array}{l}\text { RGN by } \\
\text { natice }\end{array}$ & $\begin{array}{l}\text { Ratio Index of } \\
\text { Air Fare to Gas } \\
\text { Price by one } \\
\text { percent }\end{array}$ & $\begin{array}{l}\text { Annual } \\
\text { Departures } \\
\text { by one per- } \\
\text { cent. }\end{array}$ \\
\hline $\begin{array}{l}\text { Enplaned passen- } \\
\text { gers including } \\
\text { commuters }\end{array}$ & 0.5684 & 1.2288 & -0.1613 & 0.2577 \\
$\begin{array}{l}\text { Enplaned passen- } \\
\text { gers excluding } \\
\text { commuters }\end{array}$ & 0.5824 & 1.4355 & -0.1465 & 0.1886 \\
\hline
\end{tabular}

\section{CONCLUDING NOTES}

A local newspaper reporter's interviews with Mobile city officials and representatives of airlines serving Mobile found both parties to agree that forecasts made by our model are fair. Also, no disagreement exists regarding the need for expanding the local airport facilities since the load factor out of Mobile has been hovering around 80 percent in recent months, way above the national average of about 60 percent. Detailed expansion plans are yet to be finalized, however. The major problem lies in the size of expansion. While the airlines wish to expand the existing terminal, thus minimizing costs, the city wants a more expensive new terminal to be financed by a substantial increase in landing fees. For the past few years the airlines have been paying the City of Mobile 20 cents per thousand landed pounds, when other southern cities of comparable size such as Jackson, Miss., and Pensacola, Fla. collect 40 and 39 cents, respectively. Since the airlines are currently operating under an extension clause of the contract which expired in October, 1977, a new agreement is expected before long, but early in 1979 negotiations still continue in circles. 


\section{EXHIBIT 1}

\section{SIMULATION OF MAJOR CARRIER PASSENGER ENPLANEMENTS}

\section{Enplanements}

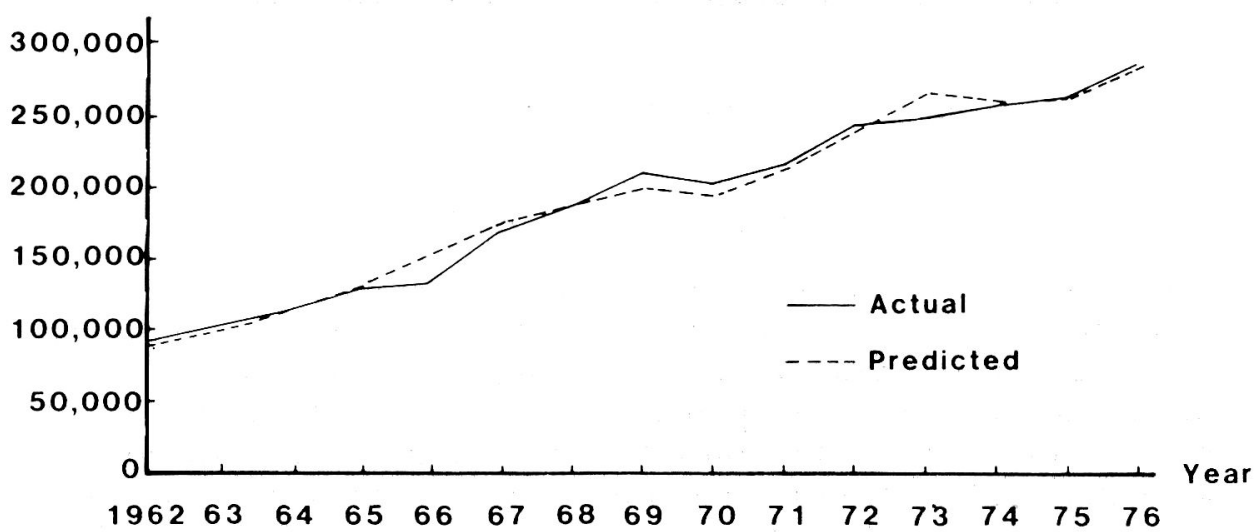

\section{FOOTNOTES}

1. David Volkert \& Associates, Mobile Airports Master Planning Study, Phase I, September, 1973, pp. 47-48, and $\mathrm{pp} .54-57$. The survey was conducted during the week of July 16 through July 22, 1973.

2. See, for example, Philip K. Verleger, Jr., "Models of the Demand for Air Transportation," The Bell Journal of Economics and Management Science, Vol. 3, No. 2 (Autumn, 1972), pp. 437-457, and S. Brown and W. S. Watkins, "The Demand for Air Travel: A Regres-

sion Study of Time Series and Cross-Sectional Data in the U. S. Domestic Market," Highway Research Record, No. 213 (1968), pp. 21-34.

3. J. E. Gorham, D. Gross, and J. C. Snipes, The Economic Impact of Energy Shortage on Commercial Air Transportation and Aviation Manufacture, Vol. 1, Impact Analysis, a study made for FAA by the Stanford Research Institute, June, 1975, pp. 40-42. 